\title{
The Role of Microfinance Services on Increasing Revenue of COOPEC COMICOKA Members, Rwanda (2010-2015)
}

\author{
Jean Bosco Harelimana ${ }^{1, *}$ \\ ${ }^{1}$ Institut d'Enseignement Superieur de Ruhengeri, Musanze, Rwanda \\ *Correspondence: Institut d'Enseignement Superieur de Ruhengeri, P.O.B. 155 Musanze, Rwanda. E-mail: \\ harelijordan@yahoo.fr
}

Received: February 20, 2017

Accepted: March 7, 2017 Online Published: April 27, 2017

doi:10.5430/mos.v4n2p29

URL: https://doi.org/10.5430/mos.v4n2p29

\begin{abstract}
The main aim of the study is to find out the role of microfinance 'services on increasing revenue of COMICOKA' members. With access to these financial savings and credit services, members can start new businesses or improve on the existing businesses and engage in any other productive activities as well as learning how to use money wisely and consequently improve on their revenue. Both primary and secondary data were collected then analyzed through MFI Factsheet, SPSS version 16.0 tools (Pearson correlation, and multi regression analysis), so that the correlation and strength between variables can have been determined.

The findings revealed that savings services were moderately favorable to members and correlation results indicates there is a strong positive relationship between savings services and members' income $(\mathrm{r}=0.784$, sig $=0.000)$. There is a strong positive relationship between credit services and members' revenue $(r=0.591$, sig $=0.000)$. From the findings, the study concludes that savings and credit at COMICOKA have got a significant effect on members' revenue. Both savings and credit services are significantly correlated with members' revenue and significantly predict member' revenue. Both savings and credit services were rated moderately.
\end{abstract}

Keywords: microfinance; microfinance services; revenue; interest rate; interest on savings; interest rates on credit ; loan size borrowed

\section{Introduction}

Throughout the world, poor people are excluded from formal financial system. Absent access to formal financial services, the poor have developed a wide variety of informal community based financial arrangement to meet their financial needs. Microfinance is created to fill this gap (Irobi, 2008).

Microfinance was known long ago in the middle ages on 1880s after the theorist Lysander Spooner was writing on the benefits from samll credits to entrepreneurs and farmers as a way getting the people out of poverty. The today use of the expression microfinance has its roots in the 1970s when organizations, such as Grameen Bank of Bangladesh with the microfinance pioneer Mohammad Yunus, where starting and shaping the modern industry of microfinance. Another pioneer in this sector is Akhtar Hameed Khan. At that time a new wave of microfinance initiatives introduced many new innovations into the sector (Otero, 1999).

Many pioneering enterprises began experimenting with loaning to the underserved people. The main reason why microfinance is dated to the 1970s is that the programs could show that people can be relied on to repay their loans and that it's possible to provide financial services to poor people through market based enterprises without subsidy. Shorebank was the first microfinance and community development bank founded 1974 in Chicago (Robinson, 2001).

In the last 45 years, microfinance had impacted positively the level of people income and poverty reduction. Microfinance pertain to the lending of small amount of capital to poor entrepreneurs in order to create a mechanism to alleviate poverty by providing the poor with resources that are available to the wealthy, alert at a small scale. According to (Anyanwu, 2004), microfinance is not just providing capital to the poor, but to also combat poverty at an individual level, it also has a role at institutional level. It seeks to create institutions that deliver financial services 
to the poor, who are continuously ignored by the formal banking sector.

In Africa and particularly in Rwanda where microfinance really started with the creation of the Union de Banques Populaires (UBPR) in 1975, microfinance institutions (MFIs) are regarded as the main source of funding micro enterprises (Rwanda Microfinance Sector Assessment 2005). Before the 1994 genocide, the level of microfinancing was characterized by slow growth and expansion of a few financial institutions, which mainly offered services in Kigali. After the genocide, many international NGOs became involved in the financial sector by implementing relief oriented microfinance initiatives, where up to now the total microfinance institutions are approximately more than 470 across the country (NBR, 2014).

Therefore as around the world, Rwandan formal credit and savings institutions for the poor are also available to customers who were traditionally neglected by commercial banks as the way to obtain financial services provided by the microfinance (MINICOFIN, 2014).

In developing countries, microfinance is one of the development tools used to reduce poverty. A lack of capital is the major constraint on the poor throughout the world; therefore the provision of financial services can be an effective tool as part of a poverty reduction strategy. The government of Rwanda complies with millennium development goals (MDGs) especially for eradicating poverty has installed the conducive environment for creation of MFIs where in space of $5 \mathrm{~km}$ radius citizens obtains financial services.

It is expected that people's consumption patterns will smooth-out if they can access the financial services. These savings and small loans can then be used, not only for future consumption, but also for emergencies, future investments, education for their children and social activities. Though all these interventions well-designed by Rwandan government to ensure the accessibility of microfinance's activities to the underserved areas of the country, it is apparent that there is no survey conducted on the role of microfinance services on increasing revenue for the microfinance participants in RWANDA.

\section{Literature Review}

Schreiner \& Colombet, (2001) define microfinance as the attempt to improve access to small deposits and small loans for poor households neglected by banks. Therefore, microfinance involves the provision of financial services such as savings, loans and insurance to poor people living in both urban and rural settings who are unable to obtain such services from the formal financial sector. Most microfinance programs, at the beginning, hold training courses to the clients in skill development, business, literacy, finance, and agriculture. Many kinds of training such as literacy, health family planning, skill development and the like, can be extremely important tools for reducing poverty (Robinson, 2001). Interest rate is a percentage return paid to savings based upon the stated period and minimum amounts (Thomas, 2007) ordinary savings pays small interest return while fixed deposit interest rate variable ( higher than other accounts). Minor savings account pays no interest and Current savings pays no interest and the lack of interest is attributed to more of inability to calculate the cost than a lack of desire for the microfinance to remunerate savings. Therefore, there is no direct incentive for members to maintain higher average balances.

Interest rate on loans is the price of accessing and utilizing credit resources. Interest rate can be looked at from the borrower (member) and the lender (microfinance) point of view. To the borrower, interest rates is the cost of borrowing money expressed as a percentage of the amount borrowed (Martin J.1996).

A borrower evaluates all costs including interest rate and expected returns before deciding to take a loan or not. To the lender, interest rate is determined by factoring in costs such as cost of production, inflation rate, operational costs, loss provision and capital growth. Interest rate should not be a burden to the lender and permits the entrepreneur to make smooth repayment of the capital and interest as said Vogel's (1996) where he commanded that it is the lender not the borrower who causes or prevents high level of delinquency in credit programs.

According to Nassuna (2003), Loan size is the quantity of money or its equivalent lent to a borrower under specific credit terms. Loan size can be small, medium or big. Nassuna argues that efficient loan sizes should fit the borrower's repayment capacity and stimulate enterprise performance. Therefore for a loan to be useful, it should be adequate to allow sufficient production to take place. She continues to say that loan sizes that are inappropriate reflect a poor fit between the objective borrowing and non performing loan, hence negatively affecting the performance of the borrower.

Welfarism is defined as a position or a methodology that evaluates individuals' welfare in a society according to their level of satisfaction with their subjective preferences (Amartya Sen, 1980). The institurionalist approach considers that 
the one best way to reach the large majority of the poor without access to financial services is to integrate microfinance in formal financial system (Woller et al. cited by Imène BERGUIGA cited by HARERIMANA ,JeanBosco ( 2015). The psychological component of the micro credit theory - known as social consciousness-Driven capitalism - has been advanced by the most ardent promoter of micro finance, Yunus (1998). The loanable funds theory states that interest rates will be determined by the supply and demand for funds. If people save more, there will be more funds for investment, this will reduce interest rates. If demand for borrowing increases, this will push up the cost of borrowing (www.economicshelp.org visited on 15/11/2016).

Microfinance has double mission like social financial mission. The welfarist theory is based on entrepreneurs increasing in income and improvement of life conditions, is a party of social mission of microfinance. The institutionalism approach which is urges the profitability and sustainability is included in financial mission. Those two approaches are complementary even if create the trade-off because of the target clients of microfinance which are the poor and lives in remote areas where outreach is very expensive. To respond on the financial mission microfinance has to cover all operating cost by a charging high interest rate. One way of solving this problem is to adapt its product and services tailored to the needs and wants of microfinance institutions 'clients. The welfare conditions cannot be improved while the microfinance institutions are not performed. And also the interest rate and other fees should be affordable to microfinance institutions' clients in the purpose of assuring the microfinance triangle (Outreach, impact and sustainable).

Sweta (2006) on paper entitled "Viability and sustainability of microfinance Institutions" have presented the meaning of microfinance as the system of grassroots development finance. It deals with the poor people, low income group, the asset less, the marginalized, the exploited and the desperate. Micro-finance provides small loans to meet their diverse needs with simple procedure in homely atmosphere. It offers other financial services such as micro insurance. Sweta focuses on the importance of microfinance as a powerful instrument in poverty alleviation is as follows:

$>$ It enables the poor to take advantages of existing opportunities

$>$ It builds up their assets

$>$ It generates self- employment

$>$ It develops micro enterprises

$>$ It raises their revenue

$>$ It builds up their self-confidence and self esteem

$>$ It improves their purchasing power and thereby consumption

$>$ It empowers them (specially women) economically and socially

$>$ It enhances overall economic growth

> It enhances domestic savings and improves financial market

$>$ It provides escape route from poverty

Micro finance according to the World Bank (2001), is "the provision of financial services to low-income clients including self-employed. It includes both financial intermediation and social intermediation. It is not simply banking, it is a development tool". It is also defined as the provision of saving, credit and other financial services and products of very small amounts to the poor in rural, semi urban or urban areas for enabling them to raise their income levels and improve living standards.

The objectives of micro-financial services are to ensure the availability of these services to the doorsteps of the poor and low-income household. It is an important financial service to uplift the level of income of low income households.

\section{Objectives}

The study was undertaken to examine the role of microfinance services on increasing the revenue in RWANDA using COMICOKA as case of study, specifically:

(1) To analyze the types of services offered to the COMICOKA Members,

(2) To assess the determinants of members revenue at COMICOKA and

(3) To measure the relationship between types of services and determinants of members revenue at COMICOKA. 
The following hypotheses have been setted in order to conduct this research:

1. Saving services, credit services and training services are the types of services offered to the COMICOKA members.

2. Volume of savings, starting new business, house improvement, schools fees payment, nutrition improvement, volume of loans are the determinants of members' revenue at COMICOKA.

3. The types of services explain positively the determinants of members revenue at Comicoka

\section{Methodology}

The research is assessing the role of microfinance services on increasing revenue of the members in COOPEC COMICOKA. The study population is 3147 accounts holders as per $31^{\text {st }}$ December, 2015 of COMICOKA from which a sample of 153 clients was purposively selected. The study adopted a combination of correlation and descriptive research design. It employed both quantitative and qualitative approaches. The research used both primary and secondary data. The primary data was collected using self-administered questionnaire, and interview while secondary data was collected using documentations techniques whereby, financial reports, bylaws, manual of procedures and credit policies of COMICOKA were consulted. The analysis of data was done via SPSS version 16.0, data entry software and Microsoft Excel. For measuring the relationship between types of services and determinants of members' income at COMICOKA a multiple linear regressions was used based on researcher made model.

$\mathbf{Y}=\boldsymbol{\beta} 0+\boldsymbol{\beta}_{1} \mathbf{X}_{1}+\boldsymbol{\beta}_{2} \mathbf{X}_{2}+\boldsymbol{\beta}_{3} \mathbf{X}_{3}+\varepsilon$

Where:

- $\quad \mathrm{Y}=$ Increasing revenue of COMICOKA members.

- $\beta 0=$ Constant Term

- $\varepsilon=$ Error term

$\mathrm{X}_{1}=$ Savings types

$\mathrm{X}_{2}=$ Interest rate on savings

$\mathrm{X}_{3}=$ Interest rate on credit

\section{Results, Findings and Discussions.}

The study was based on males opinions to a large extent due to the majority of respondents that was males (64.7\%) compared to (35.3\%) and the majority were in the age of 31-40 which was strong and economically active.

\subsection{Analysis of Increasing Revenue of COOPEC COMICOKA Members}

Dependent variable in this study was increasing income of COOPEC COMICOKA members conceptualized as increased household income and starting of new businesses and expanding the existing businesses by members of COMICOKA. In each case the respondent was asked to do self-rating in items of increased household income and starting of new businesses and expanding the existing businesses using a scale ranging from a minimum of one (for strongly disagree) to a maximum of five (for strongly agree). Thus, dependent variable was generated on the members" income. For purposes of correlating dependent with independent variables, the researcher aggregated all the 5 items/questions on increased household income and the 6 items/questions on starting of new businesses and expanding existing businesses into one index, the dependent index (using the analyze/compute = mean (variable list command in SPSS) with this index taking values ranging from a minimum of one to a maximum of five.

\subsection{Analysis of Saving Services at COMICOKA}

The section addresses independent variable, one which was on savings service terms at COMICOKA. The independent variable was operationalized as opening and running of savings accounts and interest on savings. The section also addresses specific objective two of the study, starting with description of the respective sub-sections of savings services, then their correlations and influence with the dependent variable, ending with correlation and influence of savings services on increasing income of COMICOKA' members.

\subsubsection{Opening and Running of Savings Accounts}

From respondent, It has been revealed that the procedures of opening a saving account is friendly and that the 
amount needed for opening saving account was affordable. The members of COMICOKA agreed with the statement that they can withdraw their savings when they have a need. The results indicates the members of COMICOKA agreed not to be forced to save with COMICOKA but with the statement the savings terms are flexible enough to encourage savings. There was an agreement between the management staff and the clients that opening and running of savings accounts was moderately handled.

This is in line with Thomas K. Shaw 2007, microfinance requires that members open savings account as a condition for joining but others do not. The account is maintained by the client for the purpose of accumulating funds over a period of time. Funds deposited in the savings account may be withdrawn only by the account owner or by his formally designated representative. The account may be owned by one or more persons, some accounts require funds to be kept on deposit for a minimum length of time while others permit unlimited access to the funds.

\subsubsection{Relationship between Opening and Running of Savings Accounts and Members' Income}

Pearson correlation coefficient, $(\mathrm{r}=0.695)$ shows that there was a positive and significant relationship ( $\operatorname{sig}=0.000)$ between opening and running savings accounts and increase the members' income at COMICOKA. This was an indication that if procedures for opening and running savings accounts are good or improved, members 'revenue is enhanced.

This is supported by DFID, ( 1999) where argued that microfinance contributes to enhance financial capital of livelihoods assets, which can be converted into other types of capital and be used for direct achievement of livelihoods outcomes.

\subsubsection{Interest Rates on Savings}

Service terms that savings attracted interest income was rated moderately with (Mean=3.90), interest earned on savings being adequate was rated strongly with (Mean $=4.09)$.Interest as a function of the amount of savings was rated strongly $(\mathrm{Mean}=4.69)$. However, the statement that members were always aware of how interest on savings was calculated was rated moderately with (Mean=3.49). Further, respondents are very agreed with the statement that interest on savings was always communicated which was rated strongly with (Mean=4.73) and on the method of calculating interest on savings being fair to encourage savings was also rated not sure (Mean=3.934). From the table 4.8 above, the overall mean (4.13) indicates that interest rates on savings is favorable or were properly communicated to members.

This is in line with Gittel and Vidal (2004) where they argued that microfinance aims at improving access of the poor to saving services to make them bankable clients and to promote savings mobilization among the poor through self-help groups in order to help them reduce their vulnerability by enhancing their individual and household incomes, improving their standards of living, empowering and improving household health. Savings based approaches that rely on minimal external support charge lower interest rates and a large percentage of that interest goes back to the members inform of interest on their savings and community projects.

\subsubsection{Relationship Between Interest on Savings and Members'Revenue}

Using Pearson correlation coefficient, there was a strong positive and significant relationship (.000) between Interest on saving and members' income at COMICOKA. Dhakal, (2004), highlights that financial services would assist to improve incomes and build assets of poor populace. This was an implication that if the interest rates are favorable, they enhance increase of revenue of members at COMICOKA and vice versa.

\subsubsection{Relationship between Savings Services and Members' Revenue}

Correlation results indicate that there is a strong positive relationship between savings services and members' income $(\mathrm{r}=0.784$, sig $=0.000)$. The positive relationship indicates that a directional change in the independent variable (savings services) lead to the same directional change in the dependent variable (revenue of COMICOKA' members). According to Matovu (2006), the savings services can enable clients to deal with severe business crises, cope with the shocks and to reduce vulnerability.

\subsubsection{Linear Regression Analysis}

Savings services strongly affects revenue of COMICOKA's members. $(\mathrm{R}=0.784)$ with variations in aspects of savings services contributing $61.4 \%$ to variations in revenue of COMICOKA's members. This is in line with ADB, (2000) where argued that saving services allow savers to store excess liquidity for future use and to obtain returns on their investments.

ANOVA results further show that aspects of savings services explain variations in revenue of COMICOKA's 
members. The significance value value (0.000) less than the level of significance $(0.05)$. The F-statistics $(\mathrm{F}=124.025)$ is far greater than the P-value $(0.000)$ hence a further confirmation that aspects of savings services are significantly influential requisites in the determination of members' income at COMICOKA. Further, the result indicates that the residual value (47.962) is less than the regression value (76.263) which means aspects in savings services influence members' revenue more than other factors that also influence it. These are completed with Schumpeter (1911), where he argued that the advanced services provided by financial intermediaries like the mobilization of savings, contributes to technological innovation and economic development.

A qualitative question was asked regarding suggestions to improve savings services and the following were advanced:

$>$ That savings services should be properly communicated and clearly interpreted to members.

$>$ Members should access their savings whenever there is need without any restrictions.

$>$ That members need more trainings on the benefits of savings

$>$ That COMICOKA should adopt more aggressive strategies to mobilize savings.

$>$ That savings should not be compulsory

$>$ Those interest rates on savings, how it is calculated and method of calculating it should all be communicated and known to members.

\subsection{Analysis of Credit Services at COMICOKA}

This section addresses the second independent variable and the third objective, which were credit services conceptualized as amount borrowed/size of the loan, credit period and interest on credit.

\subsubsection{Amount Borrowed}

The results revealed that the amount borrowed is adequate to undertake reasonable investment was rated highly (Mean=4.02) and ranked second done. Amount borrowed linked to the purpose of the loan was rated very strongly with (Mean=4.38 and ranked first best done and amount borrowed depends on savings made and capital paid up was also rated highly (Mean=4.02) and ranked second done ; amount borrowed is linked to the applicant's character was rated moderately (Mean=3.64) and amount borrowed graduating to bigger amounts depending on the successful payment of the previous loan was also rated also moderately (Mean=3.21) and was ranked fifth meaning that it is not at all done. These are supported by Sewagudde, (1999) where he had said the efficient loan size should fit the borrower' s capacity and stimulates economic revenue.

\subsubsection{Relationship between Amount Borrowed and Members' Revenue}

Basing on the results obtained, the Pearson correlation coefficient obtained is 0.502 and sig $=0.00$ which indicates a strong positive significant relationship between amounts borrowed (loan size) and members' revenue. This indicates that the larger the amount borrowed (loan size), the greater the level of members ${ }^{\text {ee }}$ revenue. This is in line with Adugna \& Heudhes, (2000), where he had said credit enables people to overcome their liquidity constraints and undertake some investments such as farm technology and inputs thereby increasing agricultural production.

\subsubsection{Credit Period}

The credit period is an essential element in analyzing the loan application and the credit decision should be based on a thorough evaluation of the risk conditions of the lending and the characteristics of the borrower in order to ensure the good repayment. Credit period given by COMICOKA is favorable for business growth and income generation was rated moderately (Mean=3.49). Credit period changing according the nature of loan was approach rated to be agreed (Mean=3.98) and ranked first done. Credit period is negotiable based on the capacity of repayment of the applicant was rated moderately with ( Mean =3.59); Awareness of the policies on credit was rated low $(\mathrm{Mean}=1.86)$ and was ranked lastly. Affordability of the credit period was also rated moderately (Mean=3.14) and was ranked fourth. This is in line with Ditcher, (2003) where he said that the success of lending out credit depends methodology applied to evaluate and to award the credit.

\subsubsection{Relationship between Credit Period and Members' Revenue}

Basing on the results, the Pearson correlation coefficient obtained $(s i g=.000)$ indicates a strong positive but significant relationship between the two variables that is credit period and members' revenue. This reveals that a meaningful credit period enhance members 'revenue of COMICOKA and this was well interpreted by Beckman \& Hoech ( 2000) where they have said the product or service is important when it matches the wants, beliefs, values and 
desires of the buyers not purely for fulfilling a purpose.

\subsubsection{Interest Rates on Credit}

Interest rates depending on the type of a loan was rated very strongly (Mean=4.59) and was ranked best done, satisfaction with the interest rates at COMICOKA was also rated high (Mean=4.45) and was rated second best done, method of calculating interest rates being friendly and encouraging quick recovery of loans was rated low (Mean=2.25) and was ranked fourth. Communication of interest rates was also rated moderately(Mean=3.83) and was ranked third while interest rate is negotiable for all amount was very low $(M e a n=1,23)$ and ranked fifth. Interest rate is a critical tool in microfinance institutions, once it is well defined and well implemented it permits the institution to cover its all expenses and allows the smoothness of reimbursement of the credit disbursed by the microfinance institution as it is highlighted by Vogel's (1996) where he commanded that it is the lender not the borrower who causes or prevents high level of delinquency in credit programs.

\subsubsection{Relationship between Interest Rates on Credit and Members' revenue}

Correlation results indicates that there is a positive relationship between interest rates and members' revenue $(\mathrm{r}=0.690$, $\mathrm{sig}=0.000$ ). The positive relationship indicates that a directional change in the independent variable (interest rates) lead to the same directional change in the dependent variable (members' revenue). Firstly the borrowers evaluate all costs including interest rate and expected returns before deciding to take a loan or not and is completed by Martin J.(1996) where he argued that interest rates is the cost of borrowing money expressed as a percentage of the amount borrowed.

\subsubsection{Relationship between Credit Services and Members' Revenue}

Correlation results indicates that there is a strong positive relationship between credit services and members' revenue $(\mathrm{r}=0.591$, sig $=0.000)$. The positive relationship indicates that a directional change in the independent variable (credit services ) lead to the same directional change in the dependent variable (members' revenue of COMICOKA). This is supported by Adugna and Heudhes (2000), who pointed out that credit is considered to be an essential input to increase agricultural productivity, mainly land labor. It is believed that credit boosts income levels, increases employment at household level thereby boosting income of clients and their economic development.

\subsubsection{Regression Results for Credit Services and Revenue of COMICOKA' Members}

Here, we provides the $R$ and $R^{2}$ values. The $R$ value represents the simple correlation. $\mathrm{R}=0.591$ indicates a high degree of correlation. The $R^{2}$ value indicates how much of the total variation in the dependent variable, increased revenue, can be explained by the independent variable, credit services. In this case, credit services contributing $34.9 \%$ to variations in revenue of COMICOKA' members. These are in line with Sweta (2006), where he stated micro finance as a powerful instrument of poverty alleviation is as it enables the poor to take advantages of existing opportunities, build up their assets, improve their purchasing power and thereby consumption and raising their revenue.

ANOVA results further show that aspects of credit services of explain variations in revenue of COMICOKA's members. The sig value (0.000) is less than the level significance (0.05). The F-ratio ( $\mathrm{F}=124.025)$ is far greater than the P-value (0.000) hence a further confirmation that aspects of credit services are significantly influential of members' income at COMICOKA. Further, the residual value (80.896) is greater than the regression value (43.329) which means that through aspects in credit services influence members' revnue, there are other factors that highly influence it.

Nugroho et al, (2009), noted that microfinance aims at meeting the credit needs of those excluded from formal financial services to help them finance their income generating activities, build assets, stabilize consumption and protect them against risks. When a qualitative question was raised regarding ways to improve credit services, the following suggestions were advanced:

- That loan size should be increased to reduce multiple borrowing.

- Loan size should be matched with the borrowers ${ }^{\text {ee }}$ characters, capacity to repay the loan, collateral advanced and conditions for both political and socially under which loans are given.

- Salary of the borrower should be also used to determine the loan size.

5.4 Analysis of Multiple Regression

\subsubsection{Influence of COMICOKA Services' on Members' Revenue}

Using multiple regressions, all variables, that is, savings services, and credit services were significant with (saving service terms sig $=0.030$ and credit service terms sig $=0.010$ ). Although both savings and credit services ${ }^{\text {es }}$ significantly predict members' revenue, saving services have more influence on members' income (beta $=0.585, \mathrm{t}=7.351$ ) compared 
to credit services (beta $=-0.462$ ), $\mathrm{t}=-3.623$ ) which confirms that the thrust in microfinance is on savings as suggested by Kabuga et al (1995).

\subsection{Analysis of Determinants of Members' Revenue}

\subsubsection{Evolution of Customers / Members of COMICOKA}

The interesting is that per each year the COMICOKA' customers were increased astonishingly per year in 2010 t0 2015 was respectively 577; 470; 114; 230; and 133. By comparing the years from 2010 to 2015 the evolution in percentage was respectively $31.65 \% ; 19.58 \% ; 3.9 \% ; 7.70 \%$ and $4.13 \%$. The increase show that with a lot of customers, the COMICOKA has better performance and good reputation through the services rendered. This also prove that the revenue gained by existing members, motivates others members 'adhesion in the evolution of members and permits COMICOKA to cope with outreach. Thus, the evolution of members proved what has been gathered in primary data, and showed that the COMICOKA' services increase the revenue of members of this microfinance institution. These are supported by Schreiner (2002) who worked out outreach indicators according to six dimensions, each one of which can also correspond to a component of social value: Worth of outreach measures the wealth of customers, cost of outreach measures transaction costs, scope of outreach measures the number of customers that are served, length of outreach measures the time delivery for requested services, depth of outreach measures the accuracy of targeting and breadth of outreach measures the number of services that are provided.

\subsubsection{Evolution of Members' Deposits}

The analysis of the evolution of members'deposits, during the past six years as the most important factor, shows the positive impact of COMICOKA'services to its members'revenue. Understoodly, after receing the COMICOKA'services, such as: credit services, the members were invested inn generating activities as shown in primary data, therefore, the bring the money into the COMICOKA for making the savings to its current accounts. After making a comparison, the following were discovered: the evolution was 15,782,618 in 2010 to 2011, 28,844,390 in 2011 to 2012, 33,237,102 in year 2012 to 2013; 7,479,825 in year of 2013 to 2014 and 75,739,939 in 2014 to 2015. These are in line with Mayoux (2001) where he states that microfinance services contributing to the smoothing out of peaks and troughs in income and expenditure thereby enabling the poor to cope with unpredictable shocks and emergencies.

\subsubsection{Total Values of Term Deposits}

As known, the rate of return is higher than for savings accounts. The requirement that the deposit be held for a prespecified term gives the COMICOKA the ability to invest it in a higher-gain financial product class. As tated above, the COMICOKA' services have been increased the revenue of its members, from 2010 up to 2015, the total values of terms deposits, were increased astonishingly per each year, the evolution of total values of term deposits, was changed accordance to the term deposits. Specifically, seen, from 2010 t0 2011, the $21.40 \%$ was made, 2011 to $2012,12.72 \%$, made, 2012 to 2013 , the $28.72 \%$ was made, $19.10 \%$ was happened in year of 2013 to 2014 and $15.09 \%$ was happened in year of 2014 to 2015. Even if the members know that they cannot be withdrawn for a specific term or period of time (unless a penalty is paid); they invest in this kind of accounts to increase their revenue. The COMICOKA' services affected positively the revenue of its members through the term deposits accounts. These are complied with (Morduch, 2000) in his win-win approach contends that: "Institutions following best practices are also those which succeed better in fighting poverty".

\subsubsection{Total Values of Outstanding Loans}

The interesting was that in each year the number of loans that have been neither fully repaid nor written off, and thus comprise part of the gross loan portfolio were increased. With deep analysis, from the year 2010 to 2015 the evolution in percentage was respectively $2.74 \% ; 2.41 \% ; 3.57 \% ; 5.96 \%$ and $5.33 \%$, this also show us the credit services were needed by COMICOKA's' members for increasing the business activities which will boost their revenue. Thus the outstanding loans given were contracted according to the level their income earned. As seen in table showing the level of total deposits of COMICOKA's members, were specifically corresponded to the loan contracted from all period of study. Another thing we cannot forget is that, if the members who already received the credit services have been increased their revenue and they invest into generating activities which permit to reimburse their outstanding loans. This is complied with Gurley and Shaw, (1955), contend that if income grows at a warranted pace, the demand for financial assets also grows at a specifiable pace.

The level of loans were astonishingly increased where respectively in year of 2010 to 2015 were 234,317,945; $240,753,114 ; 246,562,285 ; 255,372,203 ; 270,616,416$; and 285,055121. Depending to the size and utilization of loans , the members of COMICOKA were increased their revenue. This is in line with (Hulme \& Mosley, 1996), where they 
stated when microfinance institution provided credit to very poor households, those households were able to raise their incomes and their assets will be increased.

\subsubsection{Total Assets of COMICOKA}

By referred to diversification of loans given to its members and the term deposits of its members, the level of COMICOKA's assets, were increased, in each year, where from 2010 to 2015 the evolution of total assets were respectively $17,711,081 ; 6,415,266 ; 4,959,349 ; 14,875,458$; and 77,852274 with evolution in percentage of $4.80 \% ; 1.67 \% ; 1.26 \% ; 3.74 \%$ and $18.88 \%$ respectively .

Therefore, the increase in assets of COMICOKA, will affect also the level of its services rendered to the members specifically the credit services, where the size of loans given will increase, effectively this increase will positively impacted the members' revenue through the increasing the new business, improving existing products of its members. This is complied with Rehman (2004), where he stated that the microfinance aims at improving access of the poor to saving services to make them bankable clients and to promote savings mobilization among the poor through self help groups in order to help them reduce their vulnerability by enhancing their individual and household incomes , improving their standards of living, empowering and improving household health.

Remember that, if COMICOKA assets continue to increase the dividend allowed to its members will increase also and automatically affect the revenue of its members. By conclusion as total deposits of its members and term deposits increased, the size of COMICOKA assets increased also. This situation permits the COMICOKA to increase highly the revenue of its members.

Positively seen, the level of COMICOKA assets increased, means the increasing the revenue of its members and they have been able themselves to pay their daily expenditures as said Hashemi, (2003), "households of microfinance clients appear to have better nutrition, health practices and health education than comparable non-client households'.

The findings have proved that there are positive and significant relationship between the independent variables ( microfinance services ) and dependent variable ( increasing revenue of COOPEC COMICOKA members). Therefore, we reject null hypothesis while all hypotheses have been accepted because the results and the corresponding discussions, have proven that the savings services and credit services at COMICOKA have got a significant effect on members' revenue. Both savings and credit services are significantly correlated with members' revenue and significantly predict member' revenue.

\section{Recommendations}

The study gives the following recommendations as a result of the major findings were:

- Interest rates on savings should always be communicated to members and the same members should be aware of how interest is calculated and the method used in calculating it.

- To be complied with the microfinance principles precisely the third one which stated that microfinance means building financial systems that serve the poor, COMICOKA should minimize the amount needed for opening account in order to attract the big number of members and reach outreach easily.

- The minimum balance on saving account should be also minimized in order to keep the satisfied members

Since no work on the role of COMICOKA on the improvement of member's income has been undertaken in this study area, the study result might also initiate other researchers to conduct different research works from different perspectives, which may contribute for members 'income. The study was conducted in COOPEC COMICOKA in Rubavu District only. Similar studies may be conducted in other zones of Rwanda.

\section{References}

Hulme D., \& Mosley P. (1996). Finance against Poverty: Effective Institutions for Lending to Small Farmers and Micro-enterprises in Developing Countries: Rutledge press, London. Institutional and Financial Perspective. The World Bank: Washington D.C.

Irobi, N.C. (2008). Microfinance and Poverty Alleviation: A case study of Obazu Progressive Women Association Mbieri, Imo State-Nigeria. Uppsala: Department of Economics

Kessy, Severine S. (2006). The Contribution of Microfinance Institutions to Poverty Reduction in Tanzania. Research Report 06.3 
Matovu D. (2006). Micro finance and poverty alleviation in Uganda. Uganda.

Mayoux, L. (1998). Women's Empowerment and Microfinance programmes: Approaches, Evidence and Ways Forward. The Open University Working Paper No 41.

Morduch, J. (1998). Does Mocrofinance Really Help the Poor? New Evidence from Flagship Programs in Bangladesh. Mimeo. Stanford: Hoover Institution, Stanford University.

Otero, M. (1999). Bringing Development Back into Microfinance, This paper is based on a talk delivered by the author at the conference, New Development Finance, held nat the Goethe University in Frankfurt, September 1999.

Professor Mohamad Yunus (1983). World Bank discussion Paper. Rana Ashoke, Annual Report 2004/2005 of Rural Microfinance Development Centre Ltd, Kathmandu, Nepal.

Robinson, M. (2001). The Microfinance Revolution: Sustainable finance for the Poor. The World Bank. https://doi.org/10.1596/0-8213-4524-9

Shrestha, S.M. (2006). Viability and Sustainability of microfinance institutions. Kathmandu: RMDC.

Thomas K. Shaw (2007). SACCO saving product development training guide: USAID funded project. Chemonics international inc.

Yunus, Muhammad. (1999). Banker to the Poor: Micro-lending and the Battle Against World Poverty. New York: Public Affairs 